\title{
Mutations in the Drosophila gene extradenticle affect the way specific homeo domain proteins regulate segmental identity
}

\author{
Mark Peifer and Eric Wieschaus \\ Department of Biology, Princeton University, Princeton, New Jersey 08544-1003 USA
}

\begin{abstract}
We characterized a gene, extradenticle, which seems to interact with a specific subset of Drosophila homeo domain proteins, possibly affecting their target specificity. This interpretation is based on an examination of the zygotic and maternal effect phenotypes of extradenticle mutations. In embryos with reduced levels of extradenticle gene product, anterior and posterior segmental transformations occur. Segmental identity in Drosophila is mediated by the products of the Antennapedia and bithorax complexes. These homeo domain proteins are thought to regulate different target genes specifically in each segment, resulting in different morphologies. extradenticle alters segmental identity without affecting the pattern of expression of homeotic genes. Genetic tests demonstrate that in extradenticle mutants, the homeotic proteins are functional and act in their normal segmental domains, yet segmental identities are altered. Even when homeotic proteins are ectopically expressed under the control of a heterologous promoter, extradenticle mutations affect their consequences. Thus, in the absence of sufficient extradenticle product, altered segmental morphology results from alteration of the functional consequences of specific homeo domain proteins, possibly through alterations in their target gene specificity. extradenticle is also expressed maternally. Complete removal of extradenticle, maternally and zygotically, leads to specific alterations in segmentation, many of which result from failure to maintain the expression of the homeo domain protein engrailed.
\end{abstract}

[Key Words: extradenticle; homeo domain protein; segmental identity; engrailed]

Received February 15, 1990; revised version accepted April 26, 1990.

The establishment of pattern in a Drosophila melanogaster embryo begins before fertilization when maternal gene products set up the axes of polarity (Nüsslein-Volhard et al. 1987). By the cellular blastoderm, these maternal cues activate numerous zygotic genes. The overlapping patterns of expression of the products of these genes provide blastoderm cells with positional identities. The zygotic gap and pair-rule genes then activate the segment polarity genes, which are responsible for generating pattern within each segment (for review, see Akam 1987; Ingham 1988).

The action of these gene products alone would result in an embryo with identical segments; however, each segment has its own unique morphology. The process of assigning segmental identity is controlled by the genes of the Antennapedia and bithorax complexes (Lewis 1978; Kaufman 1983; for review, see Duncan 1987). These genes receive an extremely complex set of cues from the segmentation genes (e.g., Ingham and Martinez-Arias 1986; Ingham et al. 1986; White and Lehmann 1986), which results in complicated patterns of expression of the individual homeotic genes in the two complexes (e.g., Beachy et al. 1985; White and Wilcox
1985; Carroll et al. 1986). In the absence of a given homeotic gene, the morphology of certain segments is altered to reiterate the morphology of other segments. This role extends throughout the life of the fly /GarciaBellido and Lewis 1976; Morata and Garcia-Bellido 1976).

Molecular analysis of the homeotic genes demonstrated that they encode proteins with certain similarities. Each contains a homeo domain, a conserved set of amino acids resembling those found in the DNA-binding domain of certain bacterial regulatory genes (Laughon and Scott 1984; McGinnis et al. 1984). The homeo domain is responsible for DNA binding (e.g., Desplan et al. 1985; Beachy et al. 1988; Hoey and Levine 1988; Muller et al. 1988), and evidence is mounting that homeo domain proteins are transcription factors that interact with specific targets (Jaynes and O'Farrell 1988; Thali et al. 1988; Han et al. 1989; for review, see Levine and Hoey 1988). These observations led to the suggestion that by activating and repressing unique combinations of downstream genes, the homeotic genes confer on each segment its unique morphology.

These same molecular analyses, however, have re- 
vealed a paradox about the role of the homeotic genes. Often the homeo domains, particularly those amino acids presumed to interact with DNA, are highly conserved between homeotic genes (Gehring 1987; Scott et al. 1989). In addition, in vitro DNA binding studies reveal that the different homeo domain proteins bind in vitro to similar or identical target sequences (Beachy et al. 1988; Desplan et al. 1988; Hoey and Levine 1988). These in vitro results cannot reflect the state of affairs in vivo, where each homeotic gene product confers a unique segmental identity. How do the homeotic gene products recognize their presumed unique set of target genes, in spite of these similarities?

One approach to understanding this specificity is the search for mutations that alter it. We have examined mutations in the gene extradenticle (exd), in which the target specificity of homeotic genes appears to be altered. exd is required both for proper segmentation and for appropriate segmental identity. We used molecular and genetic probes to dissect the role of exd in these two processes. We present evidence that the alterations in segmental identity seen in embryos with reduced levels of exd gene product are not due to alterations in the expression patterns or in the domain of action of the homeotic genes. Reduced exd levels result in segmental transformations that reflect changes in the morphological consequences of the action of a small subset of the homeo domain proteins of the fly. We also show that exd is required for the maintenance of expression of another homeo domain protein, engrailed (en). These results are used to present a model for exd function.

Figure 1. The zygotic phenotype of exd. $(A)$ Ventral side of a wild-type embryo. Certain segments are numbered for comparison to the exd mutant in $B$. Each segment has a denticle belt of a characteristic shape. $(B)$ Ventral side of an embryo hemi-

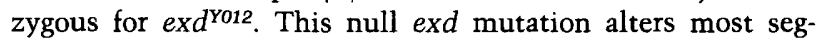
ments. Certain head derivatives, such as the $\mathrm{H}$ piece, are often severely disrupted, whereas other structures, including the antennal-maxillary complex, mouth hooks, and dorsal tooth, are often nearly normal. T1 is normal in pattern; $\mathrm{T} 2$ is partially transformed to $T 1$. Note the increased denticle size and the appearance of a rudimentary beard - the group of denticles normally found posterior to the Tl denticle belt. T3 has an ambiguous morphology, with some characteristics of both T1 and A2. The Keilin's organs and ventral pits are unchanged. Abdominal segments Al-A5 are transformed posteriorly, assuming the morphology of the segment two or three segments posterior. A6-A8 are normal or near normal. A8 sense organs are normal, as are anterior and posterior terminal structures of the embryo, including the esophagus, proventriculus, posterior spiracles, anal pads, and tuft. $(C)$ Dorsal side of a wild-type animal, showing segments $\mathrm{T} 2, \mathrm{~T} 3$, and A1. Abdominal segments differ from thoracic segments in that they have large, denticle-like dorsal hairs. T2 and T3 (small arrowhead) have none, A1 has only a few (large arrowhead), and A8 has many. $(D)$ The dorsal side of an $e x d^{X P 11}$ animal. Note the posterior transformations of all three segments, indicated by the appearance of an occasional denticle-like hair in T2 (arrow), a number of such hairs in T3 (small arrowhead), and many such hairs in A1 (large arrowhead).

\section{Results}

\section{Embryos lacking exd have segmental transformations}

exd (Wieschaus et al. 1984; Wieschaus and Noell 1986) is a zygotic, $\mathrm{X}$-linked embryonic lethal mutation that causes segmental transformations. Five exd alleles share this phenotype (Fig. 1B). These five are null or nearly null, as a similar phenotype is seen in embryos heterozygous for overlapping deficiencies removing exd $\left[D f(1) s d^{72 b}\right.$ and $\left.D f(1) L 9\right]$. Two weaker exd alleles are postembryonic lethals. Homozygotes for one of these weak alleles, exd $d^{E M 5}$, die as pharate adults with specific cuticular defects, suggesting a postembryonic role for exd.

The segmental transformations in null exd alleles are identified by use of cuticular differences between segments. Ventrally, each segment has a characteristic band

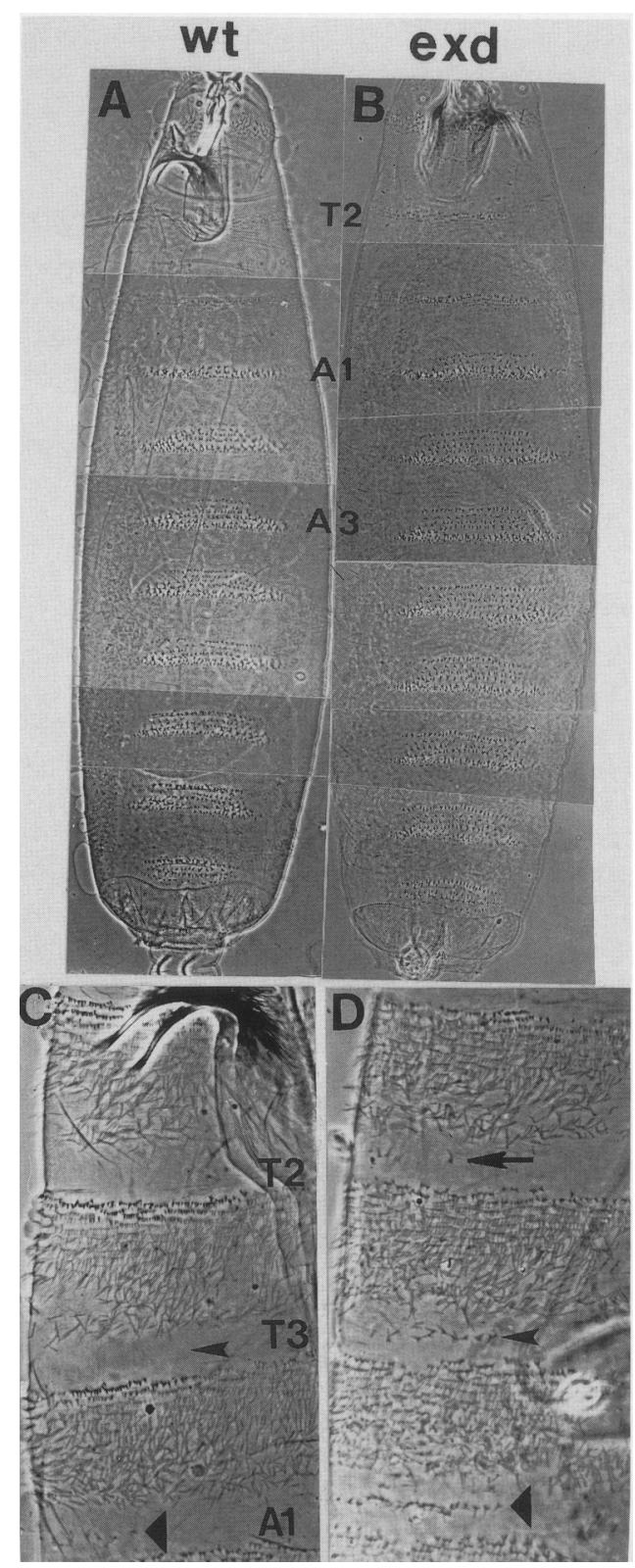


of denticles, along with specific sense organs (Fig. 1A; Campos-Ortega and Hartenstein 1985). In null exd mutant embryos, abdominal segments Al (first abdominal) to A5 adopt morphologies usually seen two to three segments more posteriorly (Fig. 1B). For example, Al looks like a wild-type A3 or A4. The most posterior abdominal segments are altered little, if at all. Some thoracic segments are transformed anteriorly. $\mathrm{T} 1$ (first thoracic segment) is unaltered. T2 is transformed partially toward $\mathrm{T} 1$, evidenced by the larger denticles and the appearance of a partial "beard," which is a second group of denticles normally found in T1. T3 adopts an ambiguous morphology. A very partial beard is formed, but there is also a rudimentary anterior row of denticles, resembling that in A2 and posterior. Most derivatives of the head are reduced, whereas the terminal, nonsegmented structures of the embryo are normal.

Dorsally, segments have specific patterns of fine dorsal hairs (Fig. 1C; Campos-Ortega and Hartenstein 1985). In exd mutants, dorsal hair alterations show that dorsal abdominal segments are transformed posteriorly (Fig. 1D). Posterior T3 (pT3) and pT2 are also transformed posteriorly. Anterior $\mathrm{T} 2$ (aT2) and aT3 seem quite normal, as does T1. The transformations are roughly parasegmental (parasegments are adjacent posterior and anterior compartments of different segments, for example, pT3 and aA1 = parasegment 6; MartinezArias and Lawrence 1985), but discrepancies between dorsal and ventral transformations and the appearance of a normal Keilin's organ on T3 straddling the parasegment boundary suggest that the rules may be more complex.

Expression patterns of homeotic genes are unaltered in exd mutants

We used genetic and molecular tests to learn how exd interacts with the homeotic genes. The homeotic genes of the Antennapedia and bithorax complexes are the central determinants of segmental identity (Lewis 1978; Kaufman 1983). Mutations in other genes result in homeotic transformations, of which genes in the Polycomb class (Lewis 1978; Struhl 1981; Duncan 1982; Jürgens 1985) are best characterized. Polycomb-like mutations resemble exd superficially, as they transform most segments into copies of A8. Polycomb-like transformations result from perturbation of homeotic gene expression. All homeotic genes become active everywhere during mid-embryogenesis (Struhl and Akam 1985; Struhl and White 1985; Wedeen et al. 1986). Because of cross-regulatory interactions between the homeotic products, all segments are transformed into A8.

To address whether exd affects homeotic gene expression, we used antisera to Antennapedia (Antp; Condie et al. 1990), Sex combs reduced (Scr; Glicksman and Brower 1988), Ultrabithorax (Ubx; White and Wilcox 1984), and abdominal-A (abd-A; Karch et al. 1990). Mixed populations of wild-type and mutant embryos were stained with the antisera to $S c r, A n t p, U b x$, and $a b d-A$ and carefully examined for any subtle alterations in pattern. All embryos exhibit a wild-type pattern of staining [data not shown; wild-type patterns are described in Mahaffey and Kaufman 1987; Riley et al. 1987 (Scr); Carroll et al. 1986; Wirz et al. 1986 (Antp); Beachy et al. 1985; White and Wilcox $1985(U b x)$; Karch et al. $1990(a b d-A)]$.

To confirm that exd does not alter homeotic gene expression, we used antiserum to Sex-lethal product (see Experimental procedures; D. Bopp and P. Schedl, pers. comm.) to identify mutant embryos unambiguously. The spatial and temporal patterns of Antp, Ubx, and $a b d-A$ expression in exd animals are indistinguishable from wild type (Fig. 2; data not shown). For example, $U b_{x}$ expression has its normal anterior margin at parasegment 5 , shows a maximal expression in parasegment 6 , switches correctly from epidermal to nervous system expression, and is repressed in the abdominal segments. The fine-scale details of cell-by-cell expression also appear normal. Most importantly, there is absolutely no detectable anterior expansion of any of these homeotic gene products at any stage. This result is in marked contrast to the effects of the Polycomb-like genes, in which effects on homeotic gene expression are seen by midgerm-band extension.

\section{In exd mutants, homeotic protein regulation of segmental identity is altered}

Normal homeotic gene expression does not necessarily mean normal activity. To assay whether homeotic genes remain active in exd mutants, we combined the null mutation exd $d^{X 11}$ with null mutations in homeotic genes. Some double and triple mutant combinations are illustrated in Figure 3, and the rest are summarized in Table 1. Although homeotic genes act in parasegmental patterns (Hayes et al. 1984; Struhl 1984), we will discuss mutant phenotypes in terms of segments, which are easier to visualize. In addition, because exd mutations cause one wild-type segment to look like another, we will distinguish between the position of a segment on the embryonic body (e.g., "Al"), and the cuticular structures found in a given segment of a wild-type embryo (e.g., the "A1 morphology").

If homeotic genes are still active in exd mutants, exd homeotic gene double mutants should differ from exd single mutants. Observation of double mutants fulfills this expectation. In each case, removal of a homeotic gene, in an exd mutant background, results in alterations in the identities of the same segments affected by that homeotic gene in the wild-type animal. Thus, in exd mutants, homeotic proteins are not only present in the appropriate segments but are also acting there to confer segmental identity. However, in exd mutants, the resultant morphology of each segment is altered, so that it resembles a different wild-type segment. This additivity is illustrated most easily by an example.

We compared the effects on segmental fate of single and double mutant combinations of exd and the homeotic gene $U b x$; the effects of these mutants on the identity of each segment are presented in a simplified form in the following diagram: 


\begin{tabular}{lccc} 
Genotype & \multicolumn{3}{c}{ Segment } \\
\hline & T2 & T3 & A1 \\
wild-type & T2 & T3 & A1 \\
Ubx & T2 & T2 & T2 \\
exd & T1 & T1/A3 & A3 \\
exd $U b x$ & T1 & T1 & T1
\end{tabular}

$U b x$ normally maintains the identity of parasegments 5 and 6 (pT2 to aA1). In an embryo mutant for $U b x, T 3$ and $\mathrm{A} 1$ are transformed into $\mathrm{T} 2$; thus, all three segments have the fine denticle belts normally found in T2 (cf. Fig. 3A with 3B; Lewis 1978). To determine, in an exd mutant, whether removal of $U b x$ has consequences (and if so, in which segments), we examined exd Ubx double mutants. Removal of $U b x$ in an exd mutant background affects only the identities of $\mathrm{T} 3$ and $\mathrm{A} 1$, which now resemble a wild-type $\mathrm{T} 1$, as would the $\mathrm{T} 2$ segment in an exd single mutant (cf. Fig. 3C with 3D). Thus, mutations in exd and $U b x$ are additive in phenotype, demonstrating that in an exd mutant embryo, $U b x$ is active in its normal domain to promote differentiation of $\mathrm{T} 3$ and $\mathrm{A} 1$ from $\mathrm{T} 2$. In the exd mutant, however, this active $U b \mathrm{x}$ has different consequences from those in a wildtype animal; for example, the Al segment assumes the morphology of a wild-type A3. The A3 morphology is usually conferred by a different homeotic gene $a b d-A$. $a b d-A$, normally active in $\mathrm{A} 2-\mathrm{A} 6$, and $A b d-B$, active in $\mathrm{A} 5-\mathrm{A} 8$, are the "abdominal" genes of the Bithorax Complex (Karch et al. 1985; Sanchez-Herrero et al. 1985). Further double and multiple mutant analyses demonstrate that the $\mathrm{A} 3$ morphology of the $\mathrm{A} 1$ segment in an exd animal (Fig. 3G) is not affected by mutations in $a b d-A$ or $A b d-B$; it is affected only by $U b x$ mutations (Fig. 3F-L). $U b x$ and $U b x$ alone is responsible for this altered abdominal morphology of A1.

What are the abdominal genes doing in an exd animal? Analyses of double and multiple mutants suggest that $a b d-A$ acts in its proper domain in an exd mutant, leading $\mathrm{A} 2-\mathrm{A} 6$ to differ from $\mathrm{A} 1$. In an exd mutant, however, $a b d-A$ has different morphological consequences than in $e x d^{+}$. For example, in an exd embryo, $a b d-A$ product results in A3 adopting the A5 morphology (cf. Fig. 3G,F,I). In contrast to $a b d-A, A b d-B$ is little affected by $e x d$. $A b d-B$ remains active in its normal segmental domain in an exd mutant, and the morphology of the segments under its control, A6-A8, is affected very little, if at all, by exd (Table 1). Further combinations of exd and Bithorax Complex mutants (Table 1) confirm that $U b x$, $a b d-A$, and $A b d-B$ are all active in their normal domains in exd embryos, but the morphological consequences of $U b x$ and $a b d-A$ are altered.

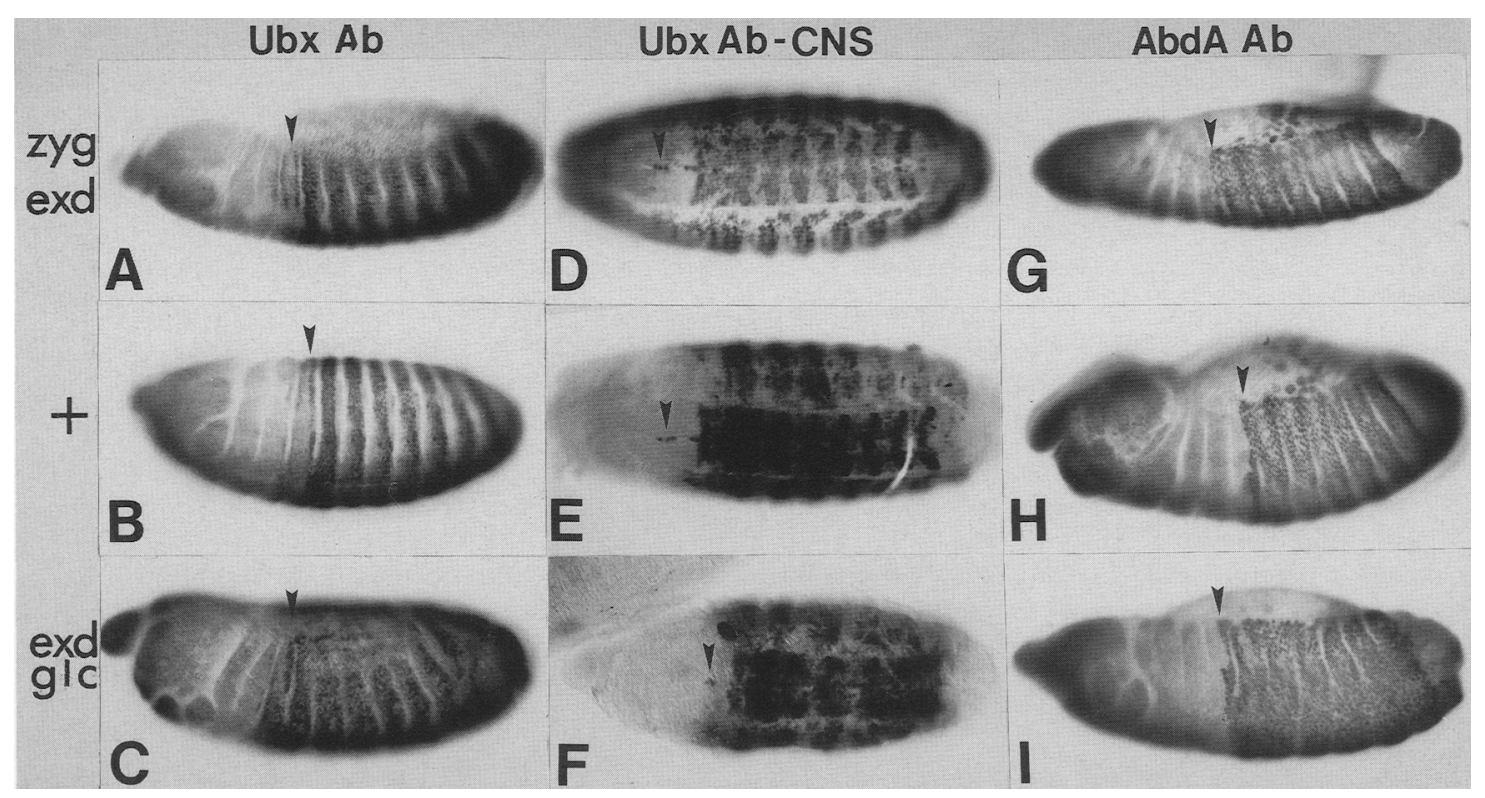

Figure 2. Homeotic gene expression in exd mutants. Embryos were assayed for expression of Ubx (left and middle columns), and abd-A (right column). Zygotic exd mutants are shown in the top row. These were identified as discussed in the text. The background staining in these embryos is higher, as they were double stained with antibody to Sex-lethal. Wild-type embryos are shown in the middle row. exd maternal effect mutants are in the bottom row (these are discussed later in the text). (A-C) Stage 14 embryos stained with antibody to $U b x$ (anterior is to left and dorsal is $u p$ ). $U b x$ expression maintains its normal anterior boundary, coming on weakly in parasegment 5 (arrowheads) and strongly in parasegment 6 . The exd maternal effect mutant has an abnormal head. (D-F) Ventral view of stage 15 embryos stained with antibody to $U b x$ (anterior is to the left). Expression of $U b x$ in the epidermis is declining, whereas CNS expression is strong. The anterior boundary of expression is still maintained, as are intersegmental differences. Note the midline cells in parasegment 4 (arrowheads). $(G-I)$ Embryos stained with antibody to $a b d-A$ (anterior is 1 eft and dorsal is up). $a b d-A$ is also expressed normally. Note the normal anterior margin at parasegment 7 (arrowheads). The exd maternal effect mutant is losing segmental grooves. 


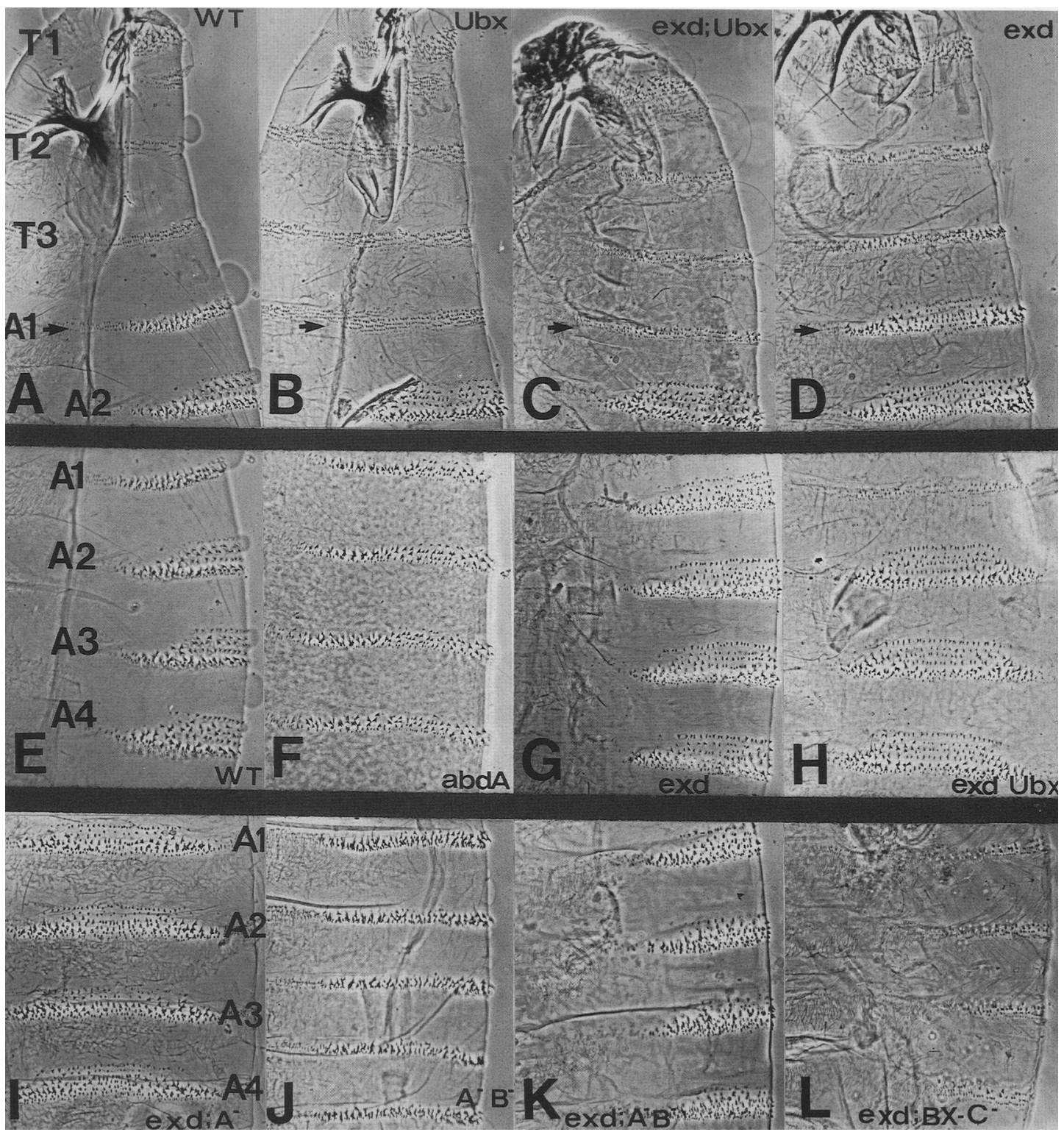

Figure 3. Homeotic genes are active in their normal domains in exd mutants. $(A-D)$ The role of $U b \mathrm{x}$ in exd mutants. T1-T3, Al, and $\mathrm{A} 2$ are shown. $\mathrm{A} 1$ is marked with an arrow for special attention. $(A)$ Wild-type embryo. A1 has a narrow band of large denticles. $(B)$ $U b x$ mutant. A1 and T3 are transformed toward T2, taking on its belt of very fine denticles. $(C$ and $D \mid$ exd Ubx double mutant $(C)$ compared to exd single mutant $(D)$. In exd, A1 has a trapezoidal belt of large denticles, whereas in the double mutant, this is transformed into a copy of the exd T2 segment. $(E-L)$ exd and the abdominal genes of the bithorax complex. Segments Al-A4 are shown. (E) Wild-type embryo. A1 has a narrow band of large denticles, the denticle band of A2 is trapezoidal, and as one proceeds posteriorly, the denticle bands become more rectangular. $(F)$ abd-A mutant. All segments shown are transformed into copies of A1. $(G)$ exd mutant. All segments shown take on the morphology of a more posterior segment. Note the trapezoidal shape of the A1 denticle belt. $(H)$ exd $U b x$ double mutant. The change in $\mathrm{A} 1$ is as described in $C$ and $D$. A2 and posterior are as in the exd single mutant. $(I)$ exd $a b d-A$ double mutant. Whereas $\mathrm{A} 1$ still resembles $\mathrm{A} 3$ in $e x d, \mathrm{~A} 2$ and posterior now are transformed into a copy of the exd A1, with less rectangular denticle belts than the exd single mutant. (I) $a b d-A A b d-B$. In the segments shown, the phenotype is identical to $a b d-A$; all denticle belts have the Al morphology. $(K)$ exd $a b d-A$ Abd-B. In the segments shown the phenotype is identical to exd $a b d-A$, with all denticle bands having the $\mathrm{A} 3$ morphology. $(L)$ exd $U b \mathrm{x}$ abd-A Abd-B. Upon removal of $U b x$, all segments now look like the $\mathrm{T} 2$ segment of an exd animal.

We also combined mutations in exd with mutations in some of the homeotic genes of the Antennapedia complex. Combinations of exd with mutations in Scr suggest that $S c r$ functions in its appropriate domain and is little affected by exd, because the morphology of $\mathrm{T} 1$, conferred by $S c r$, was not significantly changed by exd mutations (Table 1). The effect of exd on Antp is ambiguous. Both exd reduction and Antp loss result in similar 


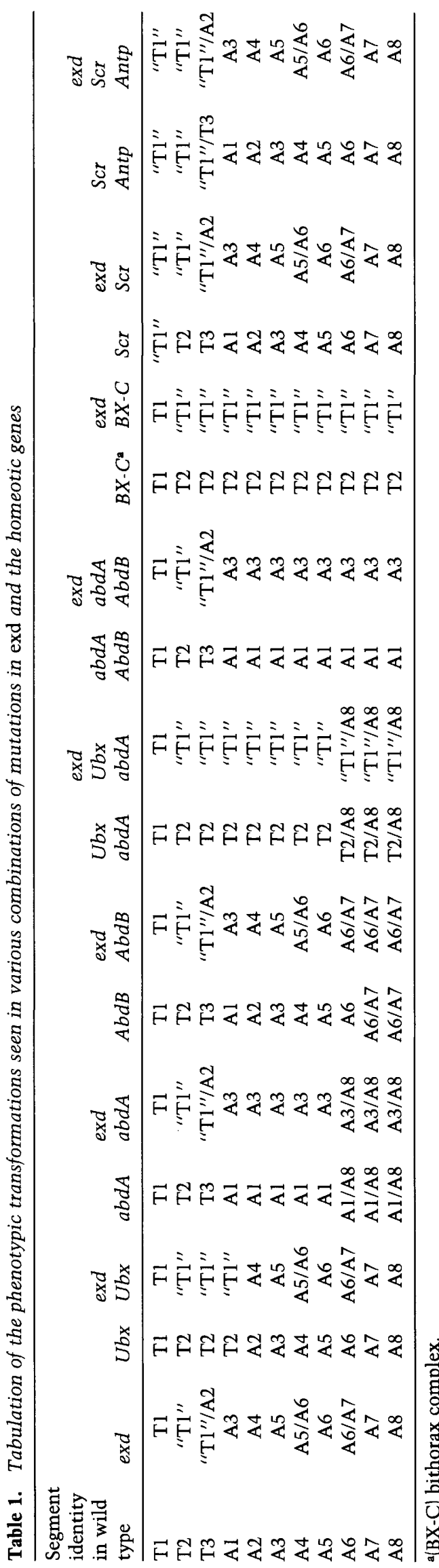

范客

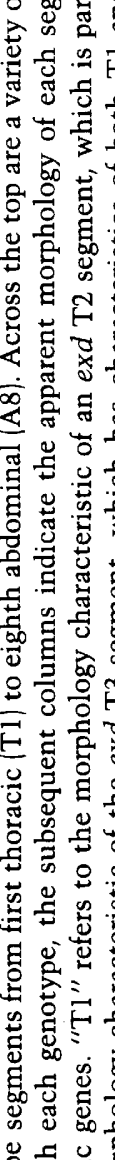

consequences for the segment Antp controls, T2. Embryos mutant for both exd and Antp seem to be identical in phenotype to exd single mutants, a conclusion supported by the phenotype of exd Scr Antp mutants (Table 1). This result is consistent with two possible conclusions. exd may alter the morphological consequences of Antp product, such that Antp confers a Tl morphology on T2, or reduced exd levels may inactivate Antp product, with the same phenotypic consequences.

We also examined the effect of exd in combination with one unusual homeotic mutation $U_{b x}{ }^{C 1}$ (Casanova et al. 1988; Rowe and Akam 1988; Table 1), which produces a fusion protein with its amino terminus derived from $a b d-A$ and its carboxyl terminus, including the homeo domain, from $U b x$. $U b x^{C 1}$ retains some specificity of both $U b x$ and $a b d-A$, giving it weak activity of both genes. The fusion also removes some information required for appropriate regulation of $U b x$ and $a b d-A$. These features combine to produce unusual segmental transformations. Despite these peculiarities, double mutants of $U b x^{C l}$ and exd are additive in phenotype, suggesting that the hybrid protein is active in its "normal" domain in an exd embryo, but that it also has its specificity altered by exd.

\section{exd also affects the consequences of ectopic homeotic gene expression}

To eliminate the possibility that exd acts via effects on homeotic gene transcription, we used constructs that fuse heat-shock regulatory elements to structural genes for homeotic proteins. When embryos carrying these fusion genes are heat-shocked, the fusions produce uniform high levels of homeotic protein throughout the embryo and transform variable numbers of segments into copies of the prototypic segment of that homeotic gene (i.e., the segment in which the homeotic gene is normally maximally expressed; Gibson and Gehring 1988; Mann and Hogness 1990). Embryos carrying a heat-shock $(h s)-U b x$ fusion, when heat-shocked and allowed to complete embryogenesis, have head and thoracic segments with the Al morphology (Fig. 4B). Al is the segment where $U b x$ expression is normally at its maximum. More posterior segments are unaffected. The effects of the $h s-U b x$ gene do not depend on the endogenous copy of $U b x$ (Mann and Hogness 1990). We also use an $h s-A n t p$ construct (provided by K. Hill and M. Scott). When embryos carrying this construct are heat-shocked, head involution is prevented and $\mathrm{T} 1$ is partially transformed toward T2 (Fig. 4D).

When embryos carrying a $h s-U b x$ construct in an exd mutant background are heat-shocked, all segments from $\mathrm{A} 1$ anterior adopt the $\mathrm{A} 3$, rather than the $\mathrm{A} 1$, morphology (Fig. 4C; more posterior segments are unaffected). A3 is the morphology A1 would have in an exd mutant in the absence of the heat-shock fusion. Reduction in the level of exd thus alters the consequences of $U b x$ expression, regardless of how it is regulated or where it is expressed. The results with the hs-Antp fusion were more ambiguous, due to the weaker and more 

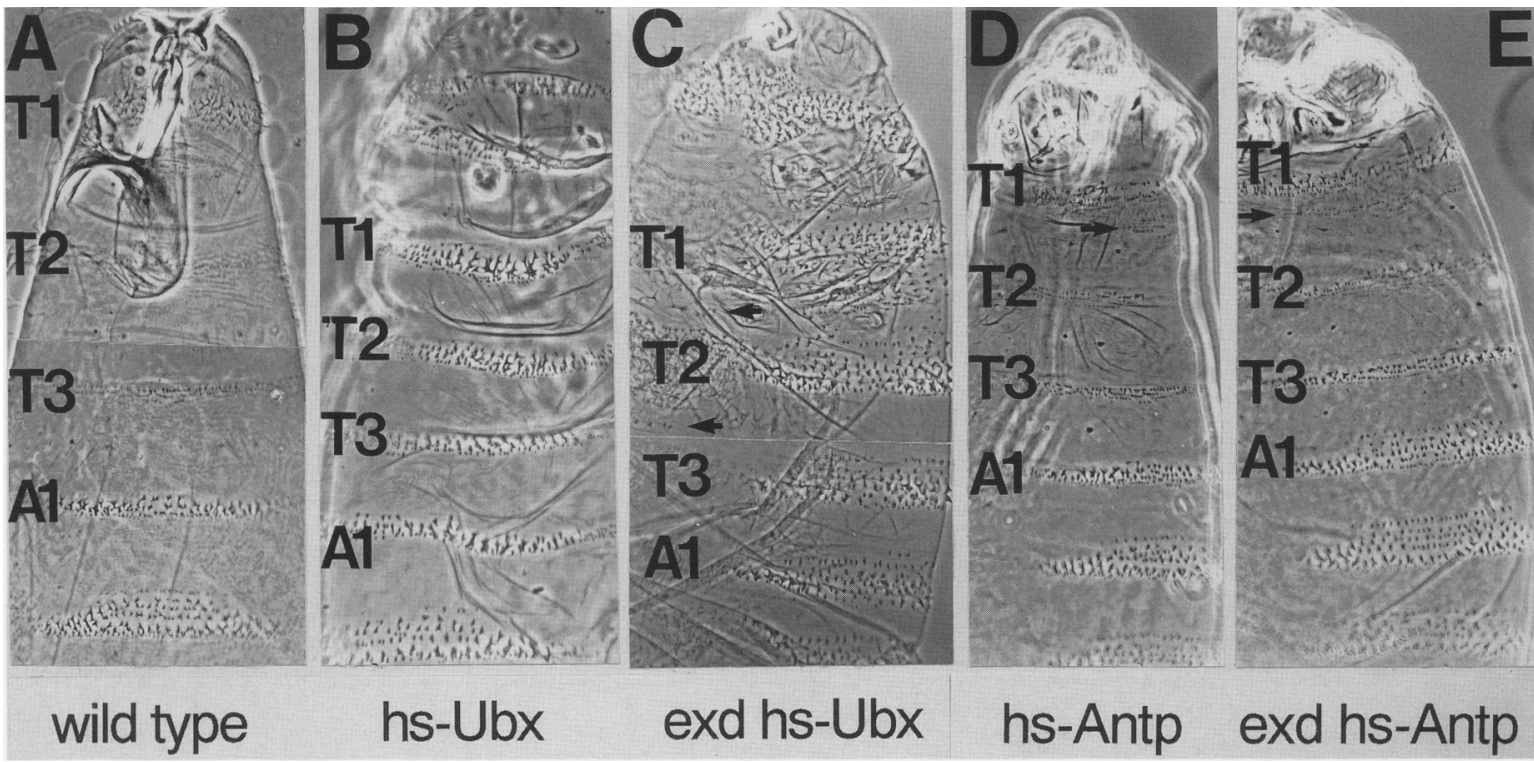

Figure 4. Effect of exd on ectopic homeotic gene expression. $\left(A \mid\right.$ Wild-type embryo. $(B)$ exd $d^{+}$embryo carrying the $h s-U b x$ construct. Several thoracic and head segments anterior to Al are transformed to the Al fate, as demonstrated by the narrow belt of large denticles. $(C)$ exd mutant carrying the $h s-U b x$ construct. The transformed head and thoracic segments assume the trapezoidal denticle belt indicative of $\mathrm{A} 3$ morphology. Arrows highlight similar transformations dorsally. $(D)$ exd $d^{+}$embryo carrying the $h s-A n t p$ construct. Head involution fails, and T1 is partially transformed toward T2, as evidenced by a reduction in both the beard (arrow) and in denticle size. $(E)$ exd mutant carrying the $h s-A n t p$ construct. Antp activity is demonstrated by failure of head involution and partial transformation of $\mathrm{T} 1$ to $\mathrm{T} 2$ (arrow).

variable nature of the $h s-A n t p$ transformations. exd mutant embryos carrying the hs-Antp fusion, when heat-shocked, fail in head involution and show a transformation of $\mathrm{T} 1$ toward an intermediate $\mathrm{T} 1 / \mathrm{T} 2$ morphology (Fig. 4E). This, together with the double mutant results, supports a model in which Antp remains active in an exd background, but the consequences of its action are altered.

When exd dose is reduced, segmental morphology is altered without altering either homeotic gene expression or the normal domains of action of homeotic genes. The effects of exd are on the consequences of homeotic proteins - the morphologies of the segments. The simplest explanation is that each homeotic gene is now regulating different downstream target genes or causing quantitatively different effects on a similar set of target genes; that is, its target specificity or its effects on its target genes are altered by a reduction in the level of exd.

\section{Maternal effect of exd-similarities and differences with en}

Segmental transformations result from the reduction in exd levels, rather than from the removal of exd entirely. In addition to exd product produced during embryogenesis, exd is also put into the egg by the mother. This maternal contribution can be demonstrated in two ways. Increasing maternal exd rescues the homeotic transformations described above, though not the lethality of exd (Wieschaus and Noell 1986; data not shown). One can also remove the maternal contribution of exd by producing clones of germ cells homozygous for exd muta- tions (Wieschaus and Noell 1986). Embryos that have no maternal contribution of $e x d$ can have two fates. If they inherit a wild-type copy of exd from their father, they survive to be fertile adults; one wild-type exd gene zygotically rescues any maternal deficit. In contrast, if they have no maternal or zygotic exd, they have a phenotype much more severe than zygotic mutants (cf. Figs. 1 and 5).

We examined the phenotype of embryos lacking both maternal and zygotic exd product by use of time-lapse video, scanning electron microscopy (SEM), and cuticle preparations. The phenotype differs drastically between the ventral and dorsal sides (cf. Fig. 5A with 5D). Embryos lacking both maternal and zygotic exd product have a dorsal closure defect (Fig. 5D). Many aspects of normal anterior-posterior polarity are still present, however, within each segment, and in the difference between thoracic and abdominal segments. Slight segmental transformations, like those in the zygotic mutant, would be too subtle to detect.

Ventrally, however, there are much more dramatic defects (Fig. 5A). The terminal, nonsegmented regions of the embryos are normal. Head involution fails, and the head skeleton is totally absent (Fig. 5D). Posterior and ventral to these head remnants is a plate of smooth, naked cuticle, in place of the ventral head and thorax (Fig. 5A and B). Occasional large denticles seen here may represent remnants of the thoracic denticle belts. The abdomen is more recognizable (Fig. 5A). Posterior to the smooth ventral region is a remnant of $\mathrm{Al}$, followed by rudimentary denticle bands, fused in a pair-rule fashion. These fusions join $\mathrm{A} 2$ to $\mathrm{A} 3, \mathrm{~A} 4$ to $\mathrm{A} 5$, and $\mathrm{A} 6$ 
Figure 5. Maternal effect phenotype of exd. All are embryos derived from exd germ-line clones, fertilized by Y-chromosome-bearing sperm. $(A-D)$ Phenotype of embryo in which both maternal and zygotic exd came from a null exd allele, exd ${ }^{X P 11}$. (A) Ventral cuticle phenotype (anterior is up). Whereas the esophagus and proventiculus are normal, the head skeleton is completely eliminated. Ventral gnathal and thoracic segments are replaced by smooth cuticle. Abdominal segments are fused in a pair-rule pattern. The denticles are poorly differentiated. The posterior end is relatively normal, with spiracles, filzkörper, anal pads, and sense organs intact. $(B$ and $C)$ A scanning electron micrograph of a stage 14 exd maternal effect embryo $(B)$, compared to a similar stage wild type $(C)$ (anterior is left and dorsal is $u p$ ). By this stage, gross morphological abnormalities are apparent. The segmental grooves in the abdomen are abnormal, whereas those in the thorax are gone (arrow). Already, the ventral thoracic and gnathal segments appear abnormally featureless. This region will give rise to the blank cuticle. The lateral head lobes do not undergo normal fusions or morphological movements, and head involution, just beginning in the wild-type embryo, will never occur in the mutant. (D) Dorsal view of the terminal phenotype of an exd germ-line clone embryo. On the dorsal side there are still relatively well-formed thoracic segments, although dorsal closure has not been completed (arrow. head). The mid-dorsal protrusion is internal tissue that is revealed by the failure to close dorsally. The large lobe at the anterior end is the clyprolabrum. Other lobes can be identified with specific head segments, which never fuse or involute but still differentiate some normal structures, such as antennal and maxillary sense organs (arrows). (E) Head and thorax of an embryo in which both maternal and zygotic exd product was provided by the weak allele, exdEM5. Whereas Al is nearly normal, the denticle bands of $\mathrm{T} 3$ and $\mathrm{T} 2$ are reduced and resemble the $\mathrm{T} 1$ beard of a wild type. The denticles and dorsal hairs of $\mathrm{T} 1$ are gone. The only remnants of $\mathrm{T} 1$ are the ventral pit (arrow) and Keilin's organ. The head is reduced, resembling the head of a zygotic, null exd mutant. The same phenotype is seen in embryos derived from germ line clones of a null allele, whose zygotic exd comes from exd $d^{\text {EMS }}$.

to A7, with A8 more posterior. The segmental fusions can be seen during development as the disappearance of segmental grooves, but only on the ventral side (Fig. 5B). This disappearance occurs in a pair-rule fashion; grooves within even-numbered parasegments disappear first, matching the pattern of denticle band fusions. The denticle belt fusions are highly reminiscent of those seen in en mutants (Nüsslein-Volhard and Wieschaus 1980; Kornberg 1981). en mutant embryos lack other defects seen in exd maternal effect embryos.

The ability of zygotic exd to rescue the lack of maternal exd and the ability of increased maternal exd to rescue the homeotic phenotype of zygotic exd mutations both suggest that maternal and zygotic exd product are functionally indistinguishable. We obtained further evidence for this by examining maternal and zygotic combinations of a null allele of exd and the weak allele exd $d^{E M 5}$. All have the same phenotype (Fig. $5 \mathrm{E}$; data not shown), which is similar but not identical to the zygotic phenotype of a null exd allele.
Complete loss of exd does not disrupt expression of the homeotic genes

Reduction in exd levels alters morphology without affecting homeotic gene expression. To determine whether total removal of exd has an effect on expression of homeotic genes, we assayed the function and expression of several homeo domain proteins, in animals from germ-line clones of null exd alleles in which both the maternal and zygotic exd contribution is removed.

The effect of the removal of both maternal and zygotic exd on expression of Antp, Scr, $U b x$, and $a b d-A$ is not very dramatic. We can identify germ line clone embryos midway through the extended germ-band stage by their altered morphology. Homeotic gene expression in these embryos, as determined by staining with the respective antibodies, remains relatively unchanged (Fig. 2C, F, and I; data not shown). Each homeotic gene is activated normally and to an approximately normal level in exd maternal effect mutants, as measured against their wild- 
type siblings. Each homeotic protein maintains an appropriate anterior boundary, undergoes a switch from ectodermal to nervous system expression, and maintains approximately correct differences in expression between segments. Some differences in the pattern within segments were noted; these differences are likely due to alterations in en expression described below (MartinezArias and White 1988).

This normality suggests that exd action is highly specific. Homeotic gene activation requires coordinated action of many maternal and zygotic genes (e.g., Ingham et al. 1986; Ingham and Martinez-Arias 1986; White and Lehmann 1986), activity of which must not be severely disrupted by exd. This renders less likely a role for exd in general cellular processes, with only indirect effects on homeotic genes, and also makes less likely any essential role for exd in the function of all homeo domain proteins, because several segmentation genes are in this class.

en expression is specifically disrupted in exd maternal effect embryos

The similarity between the exd maternal effect and the zygotic en phenotype led us to examine en expression. Expression of en is significantly altered in embryos lacking both maternal and zygotic exd (zygotic exd mu- tants have normal en expression; data not shown). We assayed en expression in two ways: by use of antibody to the invected and en proteins (Patel et al. 1989), and by use of a $\beta$-galactosidase gene under en regulation $(C$. Hama and T. Kornberg, pers. comm.). Both methods provided very similar results (Fig. 6). en is activated normally and switches from its early pair-rule pattern to its 14-stripe pattern. At mid-stage 9 (fully extended germ band), en expression deteriorates (Fig. 6A,B). Deterioration of en expression is also seen in wingless $(w g) \mathrm{mu}-$ tant embryos (DiNardo et al. 1988; Martinez-Arias et al. 1988 1, so we compared patterns of loss.

Loss of en expression in exd maternal effect mutants has dorsal/ventral, anterior/posterior, and pair-rule asymmetries (Fig. 6A-F). The deterioration is much more severe ventrally than dorsally. By germ-band shortening, although the dorsal stripes of en expression are normal or nearly normal in exd maternal effect mutants (cf. Fig. 6C with 6D), the ventral stripes have disappeared (cf. Fig. 6E with 6F). This asymmetry is not an inherent property of en decay, as the opposite pattern (stronger ventrally and weaker dorsally) is seen when en stripes deteriorate in a wg mutant (C. Rauskolb and E. Wieschaus, unpubl.). Second, head and thoracic en stripes show an earlier and more severe deterioration than abdominal stripes (Fig. 6B). Once again, this differs from the wg mutant, where the maxillary segment is

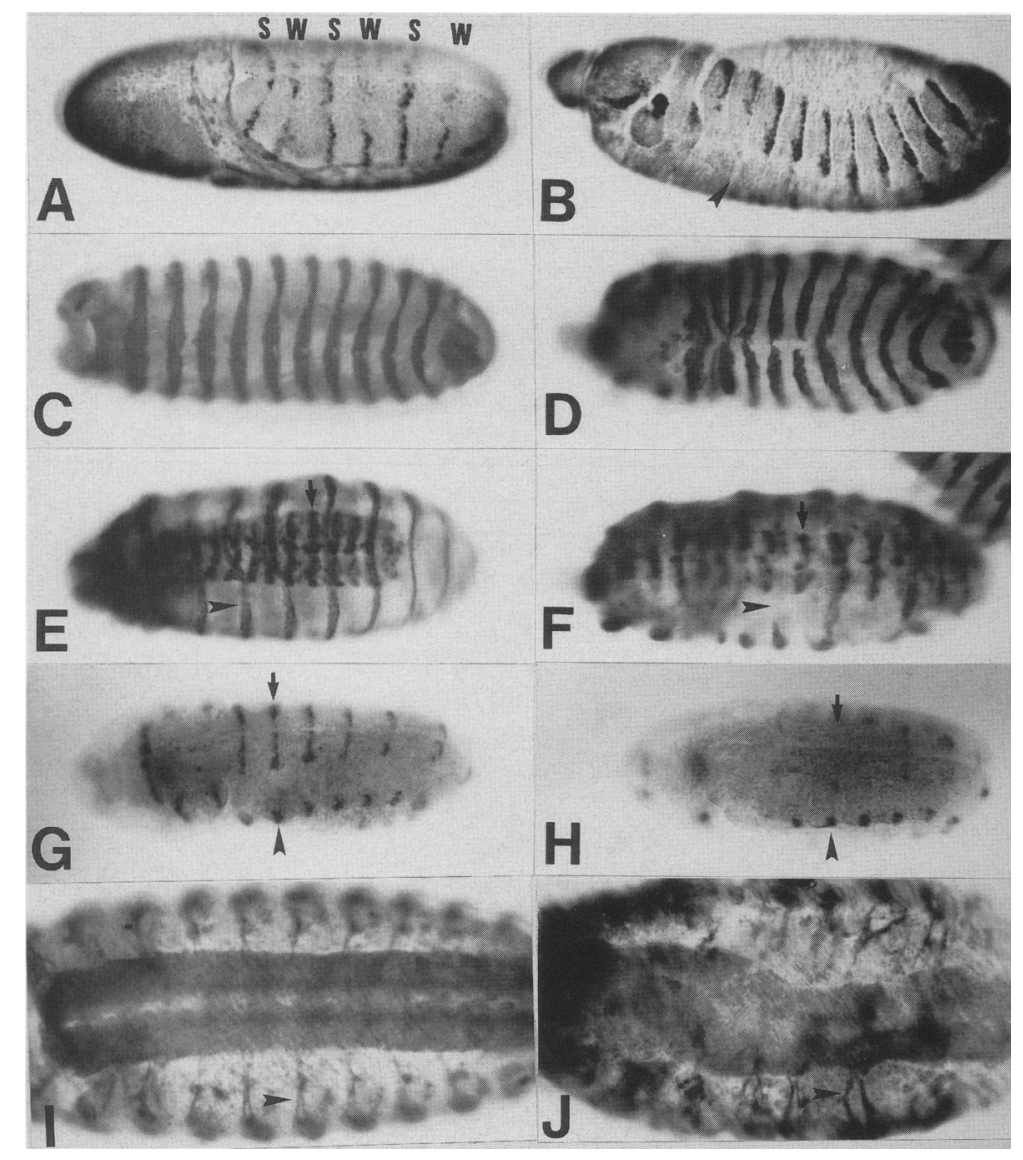

Figure 6. en expression in exd maternal effect mutants. (A) A stage 10 exd maternal effect mutant embryo, stained with monoclonal antibody to en/ invected. The ventral en stripes are starting to decay, in a pair-rule pattern. Weaker stripes $(W)$ alternate with stronger stripes (S). (B) Stage 13 maternal effect mutant. The ventral en stripes are gone in the thorax (arrowhead) and are disappearing in the abdomen. Segmental grooves are also disappearing. $(C$ and $D)$ Dorsal view of stage 15 wild-type $(C)$ and maternal effect exd mutant $(D)$ embryos, carrying a $\beta$-galactosidase gene under control of the en regulatory region. $\beta$-Galactosidase was visualized by antibody staining. The en stripes of the mutant are nearly normal dorsally, although dorsal closure was not completed. $(E$ and $F)$ Ventral views of the same wild-type $(E)$ and mutant $(F)$ embryos seen in $C$ and $D$. In the wild type, en is active in the CNS (arrow), and the epidermal en stripes remain (arrowhead). In the mutant, although CNS expression has been activated (arrow), the ventral epidermal en stripes are gone (arrowhead). ( $G$ and $H$ ) wg expression in a stage 12 wild-type $(G)$ and exd maternal effect mutant $(H)$. In the wild type, wg expression has separated into ventral stripes (arrow) and lateral patches (arrowhead). The mutant retains the lateral patches, but the ventral stripes are nearly gone. ( $I$ and $I)$ Nervous systems of a stage 15 wild-type (I) and exd maternal effect mutant $(I)$, as revealed by staining with antisera to horseradish peroxidase (Jan and Jan 1982). In the mutant, the CNS is diffuse, but axons have connected different neurons, and some axons of the peripheral nervous system have been sent out (arrowhead), though their pattern is disrupted. 
most resistant to decay (DiNardo et al. 1988). Finally, as the stripes deteriorate in an $e x d$ maternal effect mutant, the odd-numbered en stripes remain stronger than the even-numbered ones (Fig. 6A). This aspect of the loss is similar to the pair-rule en loss seen in en mutants, apparently due to failure of autoregulation, but opposite to the loss seen in wg or armadillo (DiNardo et al. 1988; J. Heemskerk, S. DiNardo, and P. O'Farrell, pers. comm.; C. Rauskolb and E. Wieschaus, unpubl.). The asymmetries seen in en expression closely parallel the asymmetries in cuticular phenotype of maternal effect exd embryos.

The asymmetries suggested that the effect of exd on en expression is not mediated through wg. As a further test, we examined $w g$ expression in embryos lacking maternal and zygotic exd (cf. Fig. 6G with $6 \mathrm{H}$; for wildtype wg expression pattern, see Baker 1987, 1988). wg comes on normally in exd maternal effect mutants; no clear change is seen until stage 10. At this point, wg expression normally shifts from uniform segmental stripes to a more complex pattern of ventral stripes and lateral patches. At stage 10, the ventral wg stripes fade in exd germ line clone embryos, whereas the lateral patches remain. wg seems to be lost slightly later than en but with a similar dorsal/ventral asymmetry. An effect on wg expression is expected, because $e n$ is required for $w g$ maintenance (Martinez-Arias et al. 1988). The effect on wg could be a secondary consequence of the loss of en expression.

Although en protein appears to have a fairly short half-life, as its pattern undergoes very rapid change, $\beta$ galactosidase protein may have a longer half-life in embryos (e.g., Klingensmith et al. 1989). Thus, changes in en promoter activity may not provide the entire explanation for the loss of expression of $\beta$-galactosidase under the control of the en promoter in exd germ line clone embryos. Instead, death of the en-expressing cells may need to be invoked.

To determine whether failure to maintain en expression resulted from disruption in an earlier step in the hierarchy of en activation, we examined the expression of the pair-rule gene fushi tarazu $(f t z)$. $f t z$ is necessary for the expression of the even-numbered en stripes (DiNardo and O'Farrell 1985; Howard and Ingham 1986; Ingham et al. 1988), those most sensitive to exd loss. Embryos lacking both material and zygotic exd were stained with $f t z$ antibody (Krause et al. 1988). Whereas half of the embryos have the extreme exd maternal effect phenotype, no difference in $f t z$ expression was seen in any of the embryos (data not shown). In fact, the correct initiation of en expression is evidence that a number of the homeo domain segmentation proteins are still functioning.

Despite dramatic loss of $e n$ in the epidermis, other tissues expressing en are less affected. en expression in the hindgut is unaltered in maternal effect exd mutants. Nervous system expression of en (DiNardo et al. 1985) is activated (Fig. 6F) and maintained after all ventral ectodermal en expression is lost. Although en expression in the nervous system is roughly normal, the nervous system as a whole is deranged (cf. Fig. 6I with $6 \mathrm{~J}$ ). The central nervous system is diffuse rather than tightly organized, but some commissures and longitudinals are formed. Some peripheral nerve axons are sent out, but their pattern is disrupted. $f t z$ and homeotic proteins are activated in the CNS of germ line clone-derived mutants (e.g., Fig. 2F), although their patterns may be disrupted.

\section{Discussion}

We demonstrated that mutations in exd disrupt a specific subset of the processes requiring the action of homeo domain proteins during Drosophila embryogenesis. One class of proteins affected is certain homeotic gene products. Reduced exd levels result in homeotic transformations, which do not result from changes in homeotic gene expression nor from effects on the domain of action of these genes. Rather, the morphological consequences of normal combinations of homeotic proteins are altered, perhaps because of changes in the segment-specific target genes recognized by these homeo domain proteins. Removal of exd from both the mother and the embryo results in a more severe phenotype which is explained, in part, by failure to maintain the expression of the homeo domain protein en.

\section{Determining segmental identity}

Segmental identity is conferred by genes of the Antennapedia and bithorax complexes (Lewis 1978; Kaufman 1983). Work from numerous laboratories has resulted in a model for how homeotic proteins regulate segmental identity. All contain a homeo domain-a protein domain required for DNA binding (for review, see Gehring 1987). The homeotic proteins are transcription factors that bind to downstream genes and turn gene expression on or off (Thali et al. 1988; Krasnow et al. 1989; Winslow et al. 1989). Each is presumed to have its own set of target genes; differential activation of these sets of target genes leads to the different morphologies of the Drosophila segments.

One problem with this model is that the homeo domain is highly conserved through evolution. Different homeo domains are often quite similar (Gehring 1987; Scott et al. 1989). For example, $U b x$ and $a b d-A$ homeo domains differ by only 5 of 61 amino acids (Akam et al. 1988). DNA binding studies of homeo domain proteins have shown that target specificity in vitro is relatively lax. Proteins with divergent homeo domains can bind the same target sequence, and the same protein can bind to two quite different targets, albeit with different affinities (Beachy et al. 1988, Desplan et al. 1988; Hoey and Levine 1988). Despite this, homeotic proteins likely recognize different subsets of target genes and also probably interact in a quantitively different fashion with common targets. The question is further complicated by the fact that the homeotic genes are not expressed in segmentwide stripes but in complex, overlapping patterns (White and Wilcox 1985; Beachy et al. 1985; Carroll et al. 1986). Different subsets of target genes must be expressed in 
response to these different patterns of homeotic gene expression. How is specificity conferred?

\section{The possible role of exd in homeotic gene specificity}

Although the genes of the Antennapedia and bithorax complexes appear to control segmental identity directly, a number of other genes have a homeotic phenotype. The precise role in segmental identity of many of these genes (e.g., Ingham and Whittle 1980; Kennison and Tamkun 1988) remains to be defined. The effects of some of these genes, members of the Polycomb-like class (Lewis 1978; Struhl 1981; Duncan 1982; Jürgens 1985|, have been examined at a molecular level. All share a similar phenotype - transformation of most segments to A8. The effects on homeotic genes of two of these genes, Polycomb and extra sex combs, have been examined by use of molecular probes and were shown to affect regulation of the Antennapedia and bithorax complexes; in mutants, all homeotic genes are ectopically expressed (Struhl and Akam 1985; Wedeen et al. 1986). These Polycomb-like genes, although homeotic in phenotype, regulate expression, not specificity of action, of the homeotic genes. Other genes in this class are more pleiotropic in their effects, but their homeotic transformations also appear to result from misregulation of the homeotic genes (e.g., polyhomeotic; Dura et al. 1985, 1987; Perrimon et al. 1985; Smouse et al. 1988).

In contrast to the Polycomb-like genes, mutations in exd do not exert their effects through alterations in homeotic gene expression. Genetic tests demonstrate that the homeotic genes are active in their normal domains in exd mutants, but this activity leads to different morphologies. Thus, exd affects the consequences of homeotic proteins, even when, as in the case of the heat shock-homeotic protein fusions, these proteins are expressed ectopically under heterologous regulation.

Having ruled out a role for exd in regulating homeotic gene expression, two possible explanations remain for the genetic additivity of mutations in exd and in the homeotic genes. One is that exd functions downstream of the homeotic genes, acting in most or all segments to turn homeotic gene expression patterns into different segmental morphologies. Such a model would almost certainly require a complicated exd expression pattern, presumably regulated by the homeotic genes, to yield different morphological consequences in each segment. Such a model can be ruled out by the interchangeability of the maternal and zygotic contributions of exd. The ability of increased maternal exd product to rescue the segmental transformations of an exd mutant rules out any essential role of the homeotic proteins in creating a complex exd expression pattern. Finally, because exd has the same effect on $U b x$ when it is expressed ectopically in the head as it does when it is expressed normally, there is probably no underlying pattern of exd expression that produces its homeotic effects.

If exd does not function downstream of the homeotic genes, it must act in parallel to them. The simplest explanations consistent with these results are that exd alters the target specificity of certain homeotic proteins or that it alters the quantitative effects of a given homeotic protein on a common target gene. Examine, for example, genes activated by $U b x$ in an exd mutant (Fig. 7). In the $\mathrm{Al}$ segment of an exd mutant, $U b x$ may activate $\mathrm{A} 3$-specific genes, rather than $\mathrm{A} 1$-specific genes. Likewise, in the A3 segment of an exd mutant, abd-A may activate A5-specific genes rather than its normal A3-specific targets. This model explains some of the more subtle aspects of the exd phenotype. T3, in an exd mutant, has an ambiguous morphology, with elements of both $\mathrm{T} 1$ and $\mathrm{A} 3$. This may be a result of a conflict between Ubx and Antp, both of which are normally active in T3. In an exd mutant, we envision that $U b \mathrm{x}$ is trying to confer the A3 morphology, whereas Antp is trying to confer the Tl morphology, leading to ambiguity. Not all homeotic proteins are equally affected, however. $S c r$ and $A b d-B$ seem relatively impervious to reduction in exd. It is interesting that the three homeotic genes clearly affected, Antp, $a b d-A$ and $U b x$, all share very similar homeo domains (Akam et al. 1988).

\section{exd and en expression}

This apparent role of exd in the specificity of the homeotic proteins arises from an analysis of lowering the level of exd product by eliminating zygotic activity. Complete removal of exd, both from the egg and the embryo, also affects segmentation. This effect seems to be mediated, in part, through alterations in the maintenance of the expression of another homeo domain protein, en.
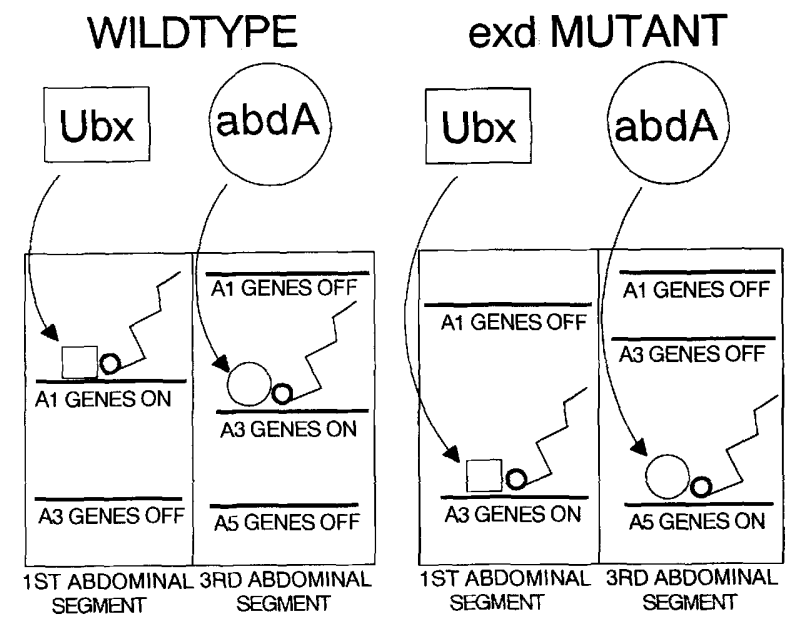

Figure 7. Model for the role of exd in homeotic gene specificity. In the wild-type animal, $U b x$ is active in the Al segment, turning on $\mathrm{Al}$-specific genes and conferring the Al morphology. Likewise, in $\mathrm{A} 3, a b d-A$ acts to turn on $\mathrm{A} 3$-specific genes, resulting in an $\mathrm{A} 3$ morphology. In contrast, in the exd zygotic mutant, each of the homeotics has altered consequences. $U b x$ continues to be active in $\mathrm{Al}$, but it now activates A3-specific genes, leading to an A3 morphology. Likewise, $a b d-A$ now activates A5-specific genes in the A3 segment, giving an A3 segment with the morphology of a wild-type A5 segment. 
As demonstrated above, exd does not affect initiation of en expression but is required for its maintenance. A number of genes are required for proper maintenance of en (DiNardo et al. 1988), prominent among which are the segment polarity genes, such as $w g$. In the absence of $w g$, en expression decays soon after its activation. Is the effect of exd on en mediated through wg? We believe not, for three reasons. (1) The cuticle phenotype of exd maternal effect mutants is similar to that of en, not $w g$; (2) although both wg and exd show asymmetries in their effects on en maintenance, these asymmetries are opposite from each other; (3) the effects on wg expression seen in $e x d$ germ line clone embryos occur after the first effects on en expression.

Another gene that affects en maintenance is $e n$ itself (J. Heemskerk, S. DiNardo, and P. O'Farrell, pers. comm.), possibly through autoregulation. The pattern of en decay in en mutant embryos shares at least one feature with the pattern of decay in $e x d$ mutants, the pairrule aspect in which even-numbered en stripes are first to decay. One speculative possibility is that exd is required for en autoregulation. Perhaps in the absence of exd, en product is no longer functional. The striking difference in the effect of exd on en between the dorsal and ventral sides is difficult to explain, though it may reflect dorsal/ventral differences in the regulation of late en expression (DiNardo et al. 1988). The aspects of the exd maternal effect phenotype that are more severe than en may reflect loss of invected (Coleman et al. 1987); a deletion of both en and invected, along with a number of other genes, is more severe than a null allele of en (Gubb 1985).

\section{The specificity of the effect of exd}

The aspects of development left unaltered by the mutations in exd tell us a number of things about the role of exd in the embryo. exd seems to play no part in oogenesis, ruling out an essential function in all cells. Numerous genes involved in segmentation, many of which have homeo domains (Gehring 1987), function properly, even in the absence of exd, as demonstrated by the appropriate activation of both the homeotic genes and $e n$. exd is quite specific in which genes it affects.

There are certain similarities between en and the homeotic genes, not shared by many other genes in the fly which encode homeo domain proteins. en and the homeotic genes are large genes with complex regulatory regions (Drees et al. 1987; Peifer et al. 1987), reflecting, in part, the fact that all of these genes are involved in specifying and maintaining the identity of specific cells. Homeotic genes regulate segmental identity, whereas en maintains differences between the anterior and posterior compartments of each segment (Morata and Lawrence 1975). These genes, in contrast to many other patterning genes, function throughout the life of the fly (Morata and Lawrence 1975; Garcia-Bellido and Lewis 1976; Morata and Garcia-Bellido 1976). These complexities and similarities may be reflected in the effect of exd on the target specificity and/or activity of all of these genes.
Given our lack of understanding of homeotic gene specificity in the wild-type animal, one can only speculate about possible molecular roles for exd. exd could, for example, form a complex with homeotic gene products, altering their specificity of DNA binding or changing the proteins with which they interact. Alternatively, because at least some of the homeotic gene products are modified by phosphorylation (Krause et al. 1988; they may also be modified in other ways), modification may modulate specificity, and exd could be involved in the modification process. All of these possibilities are completely theoretical. The molecular analysis of exd may shed some light on the function of the exd protein.

\section{Experimental procedures}

\section{Fly stocks and genetics}

Balancers and other mutants can be found in Lindsley and Grell (1968). Two exd mutants, exd $d^{X 11}$ and exd $d^{\text {YO12, }}$ along with twisted gastrulation ${ }^{\text {YN97 }}$, come from the zygotic lethal screen of Wieschaus et al. (1984). The other exd alleles were provided by Alissa Katzen as lethals from the region derived from a saturation mutagenesis. The bithorax complex mutants used, $U b x=U b x^{1}$ (Bender et al. 1983), abd-A = abd-A $A^{D 100.24}, A b d-B$ $=A b d-B^{D 100.16}, U b x$ abd-A $=D f(3 R) P 2, U b x a b d-A A b d-B=$ $D f(3 R) P 9, D P(3: 3) P 5 S b$ (used to construct all $A b d-B$ double mutants; Karch et al. 1985), and $a b d-A A b d-B=D f(3 R) M c^{R 6-41}$, were provided by Welcome Bender, except the last, which was provided by Ian Duncan. The Antennapedia complex mutants used, ScrW17, Antp W10, and $S c r^{W 17} A n t p^{W 10}$ (Wakimoto and Kaufman 1981), were provided by Ian Duncan. All of these mutants are null or nearly null for the homeotic gene they effect. The $P c$ allele used was $P c^{3}$ (Lewis 1980), and the weak en mutant was $e n^{I M 99}$ (Nüsslein-Volhard et al. 1984). Df(1)sd $d^{72 b}$ and $D f(1) L 9$ were provided by Shelagh Campbell. The hs-Ubx stock was a third chromosome-linked stock provided by Richard Mann (Mann and Hogness 1990). The hs-Antp stock, the third chromosome-linked line P2-3, was provided by Kevin Hill and Matt Scott. Most crosses were done at $22^{\circ} \mathrm{C}$. For the heat-shock experiments, males carrying the heat shock-homeotic gene fusions were mated to exd $d^{X 11}$ heterozygous females. Three-hour collections of eggs were made at $25^{\circ} \mathrm{C}$ and aged for $3 \mathrm{hr}$ more. These embryos were then transferred to a prewarmed tube of Voltalef $3 \mathrm{~S}$ oil in a $37^{\circ} \mathrm{C}$ water bath. hsUbx-bearing embryos were heat-shocked for $30 \mathrm{~min}$, and hsAntp embryos were heat-shocked for $1 \mathrm{hr}$. The heat-shocked embryos were then returned to $22^{\circ} \mathrm{C}$, allowed to complete development under oil, and mounted as described below. Germ line clones were produced as described in Wieschaus and Noell (1986). To examine the effects of increased maternal exd, yellow ${ }^{+}$attached-X females were mated to yellow exd/Duplication exd $d^{+}$males. The mutant progeny were identified by scoring for yellow denticles.

\section{Morphology}

Cuticle preparations were made according to the protocol of Struhl (1989). The observation of living embryos is described in Wieschaus and Nüsslein-Volhard (1986). Embryos were prepared for SEM as follows (many steps are described in detail in Wieschaus and Nüsslein-Volhard 1986). Embryos were collected on apple juice agar plates, washed in $0.1 \%$ Triton X-100, dechorionated in $50 \%$ bleach for $2 \mathrm{~min}$, rinsed in water, and 
fixed for $15 \mathrm{~min}$ in $25 \%$ gluteraldehyde/heptane. The fixative was removed, and embryos were devitellinized by adding methanol and shaking for $15 \mathrm{sec}$. Devitellinized embryos sink to the bottom. These were rinsed once with methanol, and rinsed $3 \times 5 \mathrm{~min}$ in $\mathrm{PBS}+0.1 \%$ Triton $\mathrm{X}-100$ and $0.2 \%$ BSA, postfixed in $1 \% \mathrm{OsO}_{4}$ at $22^{\circ} \mathrm{C}$ for $30 \mathrm{~min}$, and dehydrated through 5 -min washes in $50 \%, 70 \%, 90 \%$ and $100 \%$ ethanol. After two more washes in $100 \%$ ethanol, the embryos were incubated at $37^{\circ} \mathrm{C}$ for $30 \mathrm{~min}$ in $1: 1$ ethanol/Peldri II (Ted Pella, Inc.) and then rinsed twice and incubated for $30 \mathrm{~min}$ in Peldri. These embryos were cooled on ice to harden the Peldri, and the Peldri was then allowed to sublime under vacuum for $2-20 \mathrm{hr}$. The embryos were mounted on double-stick tape, coated with gold-palladium, and viewed under a JOEL JSM840 scanning electron microscope.

\section{Histochemistry}

Antibodies to $U b x$ (White and Wilcox 1984) and $a b d-A$ (Karch et al. 1990) were provided by Welcome Bender. Antibodies to Scr (Glicksman and Brower 1988) and Antp (Condie et al. 1990| were made by Danny Brower. Antibody to en/invected was provided by Nipam Patel (Patel et al. 1989). Antibody to $f t z$ was provided by Henry Krause (Krause et al. 1988). Antibody to Sex-lethal was provided by Daniel Bopp and Paul Schedl. Antibody to horseradish peroxidase was purchased from Cappel, and antibody to $\beta$-galactosidase was purchased from Promega. All embryo fixation and antibody staining was done according to the protocol of Patel et al. (1989). When staining with antihorseradish peroxidase, the Triton X-100 concentration in all washes was increased to $0.4 \%$. Antibody staining was visualized by use of the Vecta-stain ABC kit (Vector Labs), with the addition of $0.04 \%$ nickel chloride. Whole mount in situ hybridization was done according to the protocol of Tautz and Pfeifle (1989).

\section{Use of Sex lethal antiserum to identify exd embryos}

Antibody to Sex lethal stains female embryos but does not stain male embryos (D. Bopp and P. Schedl, pers. comm.). The progeny of a cross of wild-type males with females heterozygous for exd $d^{Y 012}$ and another closely linked X-chromosomal mutation, twisted gastrulation (Wieschaus et al. 1984), were stained with antisera to both Sex-lethal and to a homeotic gene. This resulted in three classes of progeny. Females are uniformly stained with Sex-lethal. The patterns of homeotic gene expression are visible only in male embryos. Of these, twisted gastrulation males are easily distinguished from their exd brothers by the dramatic morphological defects in twisted gastrulation.

\section{Acknowledgments}

We thank all of those who made or provided antibodies, including Welcome Bender, Daniel Bopp, Danny Brower, Sean Carroll, François Karch, Thomas Kaufman, Henry Krause, Nipam Patel, and Rob White. Richard Mann and David Hogness kindly provided us with the $h s-U b x$ stock, Kevin Hill and Matt Scott provided the $h s-A n t p$ stock, and C. Hama and Tom Kornberg provided the en- $\beta$-gal stock before publication. Jill Heemskerk, Steve DiNardo, and Pat O'Farrell shared data and discussions about en before publication. Alissa Katzen generously gave us a number of lethals from her lethal screen in the exd region, including a number of exd alleles. Other fly stocks were provided by Ian Duncan, Welcome Bender, and Shelagh Campbell. Dari Sweeton and Elaine Lenk were invaluable in completing the SEM, which was done at the Princeton Univer- sity EM Facility; Kate Harding provided very helpful advice about in situ hybridization and antibody staining; Bob Riggelman provided dioxygenin-labeled wg probe; and Gordon Gray ably ran the fly kitchen. John Scott assisted in the early stages of this work. We are indebted to Welcome Bender and members of the Wieschaus and Schüpbach laboratories for stimulating discussions and to Iva Greenwald, Bill Morgan, Cordelia Rauskolb, Lesilee Simpson, and Trudi Schüpbach for valuable comments on various drafts of the manuscript. Dari Sweeton and Kate Harding provided timely advice and help with photography. The research was funded by National Institutes of Health (NIH) grant 5R01HD22780 to E.W. and by an NIH postdoctoral fellowship to M.P.

The publication costs of this article were defrayed in part by payment of page charges. This article must therefore be hereby marked "advertisement" in accordance with 18 USC section 1734 solely to indicate this fact.

\section{References}

Akam, M. 1987. The molecular basis for metameric pattern in the Drosophila embryo. Development 101: 1-22.

Akam, M.E., I. Dawson, and G. Tear. 1988. Homeotic genes and the control of segment diversity. Development 104: (Suppl.) 123-133.

Baker, N.E. 1987. Molecular cloning of sequences from wing less, a segment polarity gene in Drosophila: The spatial distribution of a transcript in embryos. EMBO J. 6: 1765-1773.

- 1988. Localization of transcripts from the wingless gene in whole Drosophila embryos. Development 103: 289-298.

Beachy, P.A., S.L. Helfand, and D.S. Hogness. 1985. Segmental distribution of bithorax complex proteins during Drosophila development. Nature 313: 545-551.

Beachy, P.A., M.A. Krasnow, and D.S. Hogness. 1988. An U1trabithorax protein binds sequences near its own and the Antennapedia P1 promoters. Cell 55: 1069-1081.

Bender, W., M. Akam, F. Karch, P.A. Beachy, M. Peifer, P. Spierer, E.B. Lewis, and D.S. Hogness. 1983. Molecular genetics of the bithorax complex in Drosophila melanogaster. Science 221: 23-29.

Campos-Ortega, J.A. and V. Hartenstein. 1985. The embryonic development of Drosophila melanogaster. Springer-Verlag, Berlin.

Carroll, S.B., R.A. Laymon, M.A. McCutcheon, P.D. Riley, and M.P. Scott. 1986. The localization and regulation of Antennapedia expression in Drosophila embryos. Cell 47: 113 122.

Casanova, J., E. Sanchez-Herrero, and G. Morata. 1988. Developmental analysis of a hybrid gene composed of parts of the $U b x$ and $a b d-A$ genes of Drosophila. EMBO F. 7: 10971105.

Coleman, K.G., S.J. Poole, M.P. Weir, W.C. Soeller, and T. Kornberg. 1987. The invected gene of Drosophila: Sequence analysis and expression studies reveal a close relationship to the engrailed gene. Genes Dev. 1: 19-28.

Condie, J.M., J.A. Mustard, and D.L. Brower. 1990. Generation of anti-Antennapedia monoclonal antibodies, and Antennapedia protein expression in imaginal discs. Dros. Inf. Serv. (in press).

Desplan, C., J. Theis, and P.H. O'Farrell. 1985. The Drosophila developmental gene engrailed encodes a sequence specific DNA binding activity. Nature 318: 630-635.

- 1988. The sequence specificity of homeodomain DNA interaction. Cell 54: 1081-1090.

DiNardo, S. and P.H. O'Farrell. 1985. Establishment and refinement of segmental pattern in the Drosophila embryo: Spa- 
tial control of engrailed by pair-rule genes. Genes Dev. 1: $1212-1225$.

DiNardo, S., J.M. Kuner, J. Theis, and P.H. O'Farrell. 1985. Development of embryonic pattern in $D$. melanogaster as revealed by accumulation of the nuclear engrailed protein. Cell 43: 59-69.

DiNardo, S., E. Sher, J. Heemskerk-Jongens, J.A. Kassis, and P.H. O'Farrell. 1988. Two-tiered regulation of spatially patterned engrailed expression during Drosophila embryogenesis. Nature 332: 604-609.

Drees, B., Z. Ali, W. Soeller, K. Coleman, S. Poole, and T. Kornberg. 1987. The transcription unit of the Drosophila engrailed locus: An unusually small portion of a 70,000 bp gene. EMBO I. 6: 2803-2809.

Duncan, I. 1982. Polycomblike: A gene that appears to be required for the normal expression of the bithorax and antennapedia gene complexes of Drosophila melanogaster. Genetics 102: 49-70.

. 1987. The bithorax complex. Annu. Rev. Genet. 21: $285-319$.

Dura, J.-M., H.W. Brock, and P. Santamaria. 1985. polyhomeotic: A gene of Drosophila melanogaster required for correct expression of segmental identity. Mol. Gen. Genet. 198: $213-220$.

Dura, J.-M., N.B. Randsholt, J. Deatrick, P. Erk, P. Santamaria, J.D. Freeman, S.J. Freeman, D. Weddell, and H.W. Brock. 1987. A complex genetic locus, polyhomeotic, is required for segmental specification and epidermal development in D. melanogaster. Cell 51: 829-839.

Garcia-Bellido, A. and E.B. Lewis. 1976. Autonomous cellular differentiation of homeotic bithorax mutants of Drosophila. Dev. Biol. 48: 400-410.

Gehring, W.J. 1987. Homeoboxes in the study of development. Science 236: 1245-1252.

Gibson, G. and W.J. Gehring. 1988. Head and thoracic transformations caused by ectopic expression of Antennapedia during Drosophila development. Development 102: 657675.

Glicksman, M.A. and D.L. Brower. 1988. Expression of Sex combs reduced protein in Drosophila larvae. Dev. Biol. 127: $113-118$.

Gubb, D. 1985. Further studies on engrailed mutants in Drosophila melanogaster. Wilhelm Roux's Arch. Dev. Biol. 194: 236-246.

Han, K., M.S. Levine, and J.L. Manley. 1989. Synergistic activation and repression of transcription by Drosophila homeobox proteins. Cell. 56: 573-583.

Hayes, P.H., S. Sato, and R.E. Denell. 1984. Homeosis in Drosophila: The Ultrabithorax larval syndrome. Proc. Natl. Acad. Sci. 81: 545-549.

Hoey, T. and M. Levine. 1988. Divergent homeo box proteins recognize similar DNA sequences in Drosophila. Nature 332: $858-861$.

Howard, K. and P. Ingham. 1986. Regulatory interactions between the segmentation genes fushi tarazu, hairy, and engrailed in the Drosophila blastoderm. Cell 44: 949-957.

Ingham, P.W. 1988. The molecular genetics of embryonic pattern formation in Drosophila. Nature 335: 25-34.

Ingham, P.W. and A. Martinez-Arias. 1986. Correct activation of Antennapedia and bithorax complex genes requires the fushi tarazu gene. Nature 324: 592-597.

Ingham, P.W. and R. Whittle. 1980. Trithorax: A new homeotic mutation of Drosophila melanogaster causing transformations of abdominal and thoracic imaginal segments. I. Putative role during embryogenesis. Mol. Gen. Genet. 179: 607614.
Ingham, P.W., N. Baker, and A. Martinez-Arias. 1988. Positive and negative regulation of segment polarity genes in the Drosophila blastoderm by the pair-rule genes fushi tarazu and even skipped. Nature 331: 73-75.

Ingham, P.W., D. Ish-Horowicz, and K.R. Howard. 1986. Correlative changes in homeotic and segmentation gene expression in Krüppel mutant embryos of Drosophila. EMBO $I$. 5: 1659-1665.

Jan, L.Y. and Y.N. Jan. 1982. Antibodies to horseradish peroxidase as specific neuronal markers in Drosophila and in grasshopper embryos. Proc. Natl. Acad. Sci. 79: 2700-2704.

Jaynes, J.B. and P.H. O'Farrell. 1988. Activation and repression of transcription by homeodomain proteins that bind a common site. Nature 336: 744-7.49.

Jürgens, G. 1985. A group of genes controlling spatial expression of the bithorax complex in Drosophila. Nature 316: $153-155$.

Karch, F., B. Weiffenbach, M. Peifer, W. Bender, I. Duncan, S. Celniker, M. Crosby, and E.B. Lewis. 1985. The abdominal region of the bithorax complex. Cell 43: 81-96.

Karch, F., W. Bender, and B. Weiffenbach. 1990. $a b d A$ expression in Drosophila embryos. Genes Dev. (in press).

Kaufman, T.C. 1983. The genetic regulation of segmentation in Drosophila melanogaster. In Time, space, and pattern in embryonic development (ed. W.R. Jeffrey and R.A. Raff), pp. 365-383. Alan R. Liss, New York.

Kennison, J.A. and J.W. Tamkun. 1988. Dosage dependent modifiers of Polycomb and Antennapedia mutations in Drosophila. Proc. Natl. Acad. Sci. 85: 8136-8140.

Klingensmith, J., E. Noll, and N. Perrimon. 1989. The segment polarity phenotype of Drosophila involves differential tendencies toward transformation and cell death. Dev. Biol. 134: $130-145$.

Kornberg, T. 1981. engrailed: A gene controlling compartment and segment formation in Drosophila. Proc. Natl. Acad. Sci. 78: $1095-1099$.

Krasnow, M.A., E.E. Saffman, K. Kornfeld, and D.S. Hogness. 1989. Transcriptional activation and repression by Ultrabithorax proteins in cultured Drosophila cells. Cell 57: $1031-1043$.

Krause, H.M., R. Klemenz, and W.J. Gehring. 1988. Expression, modification, and localization of the fushi tarazu protein in Drosophila embryos. Genes Dev. 2: 1021-1036.

Laughon, A. and M.P. Scott. 1984. Sequence of a Drosophila segmentation gene: protein structure homology with DNAbinding proteins. Nature 310: 25-31.

Levine, M. and T. Hoey. 1988. Homeobox proteins as sequencespecific transcription factors. Cell 55: 537-540.

Lewis, E.B. 1978. A gene complex controlling segmentation in Drosophila. Nature 276: 565-570. . 1980. New mutants-D. melanogaster. Dros. Inf. Serv. 55: 207-208.

Lindsley, D.L. and E.H. Grell. 1968. Genetic variations of .MD44/.MDNM/Drosophila melanogaster. Carnegie Inst. Washington, Publ. No. 627.

Mahaffey, J.W. and T.C. Kaufman. 1987. Distribution of the Sex combs reduced gene products in Drosophila melanogaster. Genetics 117: 51-60.

Mann, R.S. and D.S. Hogness. 1990. Functional dissection of Ultrabithorax proteins in Drosophila melanogaster. Cell 60: $597-610$.

Martinez-Arias, A. and P. Lawrence. 1985. Parasegments and compartments in the Drosophila embryo. Nature 313: 639642.

Martinez-Arias, A. and R.A.H. White. 1988. Ultrabithorax and engrailed expression in Drosophila embryos mutant for seg- 
mentation genes of the pair-rule class. Development 102: $325-338$.

Martinez-Arias, A., N.E. Baker, and P.W. Ingham. 1988. Role of segment polarity genes in the definition and maintenance of cell states in the Drosophila embryo. Development 103: $157-170$.

McGinnis, W., M. Levine, E. Hafen, A. Kuroiwa, and W.J. Gehring. 1984. A conserved DNA sequence found in homeotic genes of the Drosophila Antennapedia and bithorax complexes. Nature 308: 428-433.

Morata, G. and A. Garcia-Bellido. 1976. Developmental analysis of some mutants of the bithorax system of Drosophila. Wilhelm Roux's Arch. Dev. Biol. 179: 125-143.

Morata, G. and P.A. Lawrence. 1975. Control of compartment development by the engrailed gene in Drosophila. Nature 255: 614-617.

Muller, M., M. Affolter, W. Leupin, G. Otting, K. Wuthrich, and W.J. Gehring. 1988. Isolation and sequence-specific DNA binding of the Antennapedia homeodomain. EMBO $I$. 7: 4299-4304.

Nüsslein-Volhard, C. and E. Wieschaus. 1980. Mutations affecting segment number and polarity in Drosophila. Nature 287: 795-801.

Nüsslein-Volhard, C., H.G. Frohnhöfer, and R. Lehmann. 1987. Determination of anteroposterior polarity in Drosophila. Science 238: 1675-1681.

Nüsslein-Volhard, C., E. Weischaus, and E. Kluding. 1984. Mutations affecting the pattern of the larval cuticle in Drosophila melanogaster. I. Zygotic loci on second chromosome. Wilhelm Roux's Arch. Dev. Biol. 193: 267-282.

Patel, N., E. Martin-Blanco, K.G. Coleman, S.J. Poole, M.C. Ellis, T.B. Kornberg, and C.S. Goodman. 1989. Expression of engrailed proteins in arthropods, annelids, and chordates. Cell 58: 955-968.

Peifer, M., F. Karch, and W. Bender. 1987. The bithorax complex: Control of segmental identity. Genes Dev. 1: 891-898.

Perrimon, N., L. Engstrom, and A.P. Mahowald. 1985. Developmental genetics of the 2C-D region of the Drosophila X chromosome. Genetics 111: 23-41.

Riley, P.D., S.B. Carroll, and M.P. Scott. 1987. The expression and regulation of Sex combs reduced protein in Drosophila embryos. Genes Dev. 1: 716-730.

Rowe, A. and M. Akam. 1988. The structure and expression of a hybrid homeotic gene. EMBO 1. 7: 1107-1114.

Sánchez-Herrero, E., I. Vernós, R. Marco, and G. Morata. 1985. Genetic organization of the Drosophila bithorax complex. Nature 313: 108-113.

Scott, M.P., J.W. Tamkun, and G.W. Hartzell. 1989. The structure and function of the homeodomain. Biochim. Biophys. Acta. 989: 25-48.

Smouse, D., C. Goodman, A. Mahowald, and N. Perrimon. 1988. polyhomeotic: A gene required for the embryonic development of axon pathways in the central nervous system of Drosophila. Genes Dev. 2: 830-842.

Struhl, G. 1981. A gene product required for correct initiation of segmental determination in Drosophila. Nature 293: 3641.

- 1984. Splitting the bithorax complex of Drosophila. $\mathrm{Na}$ ture 308: 454-457.

- 1989. Differing strategies for organizing anterior and posterior body pattern in Drosophila embryos. Nature 338: $741-744$.

Struhl, G. and M. Akam. 1985. Altered distribution of Ultrabithorax transcripts in extra sex combs mutant embryos of Drosophila. EMBO I. 4: 3259-3264 .

Struhl, G. and R.A.H. White. 1985. Regulation of the Ultra- bithorax gene of Drosophila by other bithorax complex genes. Cell 43: 507-519.

Tautz, D. and C. Pfeifle. 1989. A nonradioactive in situ hybridization method for the localization of specific RNAs in Drosophila embryos reveals translational control of the segmentation gene hunchback. Chromosoma 98: 81-85.

Thali, M., M.M. Muller, M. DeLorenzi, P. Matthias, and M. Bienz. 1988. Drosophila homeotic genes encode transcriptional activators similar to mammalian OTF-2. Nature 336: $598-600$.

Wakimoto, B.T. and T.C. Kaufman. 1981. Analysis of larval segmentation in lethal genotypes associated with the Antennapedia gene complex in Drosophila melanogaster. Dev. Biol. 81: 51-64.

Wedeen, C., K. Harding, and M. Levine. 1986. Spatial regulation of Antennapedia and bithorax gene expression by the Polycomb locus in Drosophila. Cell 44: 739-748.

White, R.A.H. and R. Lehmann. 1986. A gap gene hunchback regulates the spatial expression of Ultrabithorax. Cell 47: $311-321$.

White, R.A.H. and M. Wilcox. 1984. Protein products of the bithorax complex in Drosophila. Nature 318: 563-567.

. 1985. Distribution of Ultrabithorax proteins in Drosophila. EMBO J. 4: 2035-2043.

Wieschaus, E. and E.F. Noell. 1986. Specificity of embryonic lethal mutations in Drosophila analysed in germ line clones. Wilhelm Roux's Arch. Dev. Biol. 195: 63-73.

Wieschaus, E. and C. Nüsslein-Volhard. 1986. Looking at embryos. In: Drosophila, a practical approach (ed. D.B. Roberts), pp. 199-227. IRL Press, Oxford.

Wieschaus, E., C. Nüsslein-Volhard, and G. Jürgens. 1984. Mutations affecting the pattern of the larval cuticle in Drosophila melanogaster. III. Zygotic loci on the X-chromosome and fourth chromosome. Wilhelm Roux's Arch. Dev. Biol. 193: $296-307$.

Winslow, G.M., S. Hayashi, M. Krasnow, D.S. Hogness, and M.P. Scott. 1989. Transcriptional activity by the Antennapedia and fushi tarazu proteins in cultured Drosophila cells. Cell 57: 1017-1030.

Wirz, J., L.I. Fessler, and W.J. Gehring. 1986. Localization of the Antennapedia protein in Drosophila embryos and imaginal discs. EMBO /. 5: 3327-3334. 


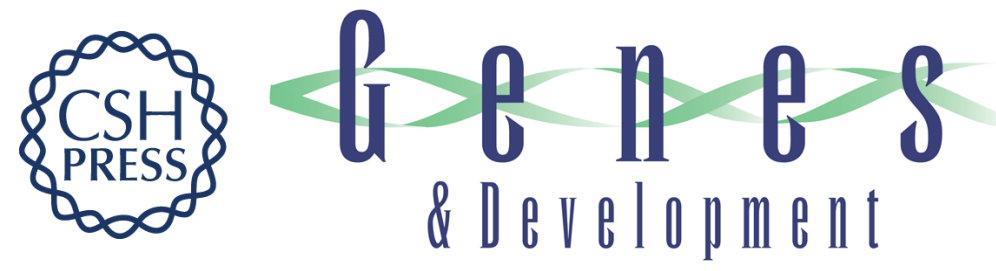

\section{Mutations in the Drosophila gene extradenticle affect the way specific homeo domain proteins regulate segmental identity.}

M Peifer and E Wieschaus

Genes Dev. 1990, 4:

Access the most recent version at doi:10.1101/gad.4.7.1209

References This article cites 83 articles, 20 of which can be accessed free at: http://genesdev.cshlp.org/content/4/7/1209.full.html\#ref-list-1

License

Email Alerting

Service

Receive free email alerts when new articles cite this article - sign up in the box at the top right corner of the article or click here.

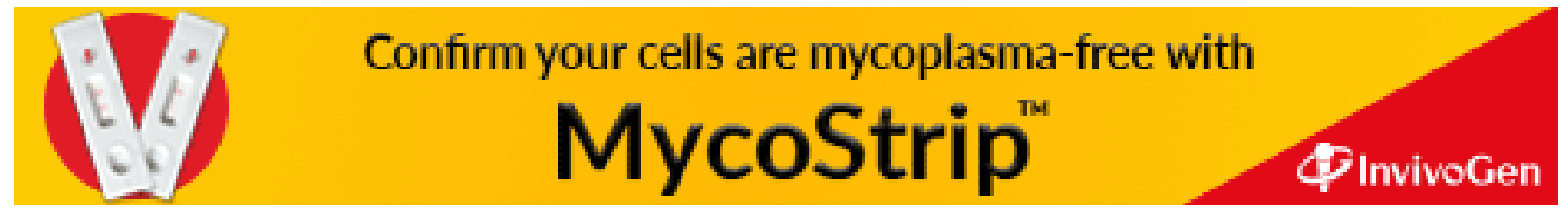

